\title{
Drawing a line in the sand: social mapping of responses to calls to 'decolonise the university'
}

\author{
JDD, Vol 3 No 12021 \\ DOI: https://doi.org/10.35293/jdd.v3i1.26 \\ Kasturi Behari-Leak \\ University of Cape Town \\ Rajendra Chetty \\ University of the Western Cape
}

\section{Abstract}

The task of decolonisation is convoluted as the complexities of meanings as well as the multiple dimensions of decolonisation are vast and textured, depending on one's vantage point and vested interests. This situation warrants a critical examination of what decolonisation has come to mean in the global South and how different subjectivities at a particular academic institution in the country are responding to the call for change.

The academic, social and political movement of decolonisation evokes a variety of reactions, responses and repercussions from a wide spectrum of the university community and its stakeholders. Ranging from conservative to radical, these responses reflect the range of discourses, values, beliefs and actions that the academic community embraces and might determine the extent to which the decolonisation movement can in fact succeed in its goals. This paper critically analyses responses to the calls for decolonisation of the academy by the \#MustFallist student movements, which were historically preceded by activism in many forms in the university space. The aim is to ascertain whether the vision for transforming a largely socially exclusive and unjust academic project into one that is socially just, inclusive and transformed can be actualised in spite of resistance from those who wish to maintain the status quo. Drawing on the work of Andreotti, Stein, Ahenakew, \& Hunt (2015), the paper uses social cartography (Paulston, 2009) as a discursive and analytical tool to understand the vocabularies and imaginaries of decolonisation at a research-intensive, traditional university. 


\section{Introduction}

Decolonial efforts in South African universities, which have a long history of being driven by scholars, students and decolonial activists, created a framing and context for calls for the decolonisation of the academy that emerged initially in March 2015, as an outcome of the formation of the \#RhodesMustFall movement, then in October 2015 when the \#FeesMustFall movement resisted fee increases. Protesting students contested and challenged the political and social history of the academy and held universities to account for their culpability in the colonial project (Farber, 2015). This student disruption of business-as-usual practices in academia caused the country and the global South in particular, to look critically at how the university has been complicit in the reproduction of unjust historical practices such as marginalising, making invisible, silencing and alienating the Other, in public institutions across the country (Duma, 2017). Calls for change were theorised by activist students and scholars using decolonisation/decoloniality as critical frames to re-examine new ways of working with the local academic project (Gordon, 2019).

The academic, social and political movement of decolonisation has evoked a mixed set of reactions from the university community, based on different interlocutors' vantage points, positionality and intellectual or vested interests. Using a social cartographic analysis, we sharpen our gaze on how student activists and academics are responding and reacting to the decolonisation movement. The aim of the chapter is to ascertain whether the decolonisation movement at universities can in fact succeed in its goals.

The paper concludes by outlining the implications for decolonisation in higher education and the need for strategies to move the decolonisation project further. The change advocated here is around the inclusion of alternate knowledge frameworks, which leads to democratisation of knowledge by supporting epistemic plurality. Our concern is whether the decolonisation movement has been co-opted by traditional research-intensive universities, as another tick-box project that academia can claim it owns, because it has 'researched' it, even though these claims bear little or no commitment to real change in the sector.

\section{Decolonial turns and epistemic perspectives}

The critical move from the global South to disrupt the master narrative by engaging with alternate knowledge frameworks and democratisation of knowledge by disrupting particular epistemic gridlocks on theory and content choices emphasise the Decolonial Turn 
(Mignolo, 2011). Alternate forms of knowing with different theoretical, epistemological and ontological bases need to be brought into the frame not only to disrupt hegemonic practices but to ensure that alternate voices, subjectivities and positionalities are foregrounded as important and legitimate sources of knowledge too (Nakata, Nakata, Keech and Bolt, 2012). Epistemic traditions mainly from the global north have historically locked us into viewing the world through limited lenses (Dastile and Ndlovu-Gatsheni, 2013), making the credibility of Other voices harder to establish against knowledge that is considered to be mainstream and central (Quijano, 2007). Drawing on Latin-American scholarship, we focus on three critical frames: power, knowledge, and being; and argue that they reinstate colonial privilege. These frames are essential to change the content of current intellectual conversations that are framed as counter-productive (in our analysis) and do not address the decolonial agenda effectively. Each of these frames is contextualised by further drawing on African scholarship to provide nuance and texture. The decolonial turn requires a generative conversation across different colonial contexts to bring different voices into the fold.

Coloniality of power characterised by capitalism and neoliberal commodification, locates knowledge within the context of a racist, Euro-America-centric, Christian-centric, patriarchal, hetero-normative, hegemonic, asymmetrical, and modern global power structure (Grosfoguel, 2013). The westernised university is a 'world problem' because no matter where a student enrols, one is likely to find the same curriculum, the same authors and the same disciplinary divisions. Coloniality of power is a critical concept underpinning decolonial epistemic perspectives in Africa. For example, development, a dominant discourse in the humanities, is not innocent of power. Development cannot be reduced to simple real-life problems of hunger, water scarcity, disease, malnutrition and poverty, as if these were unshaped by broader questions of power, epistemology, representation and identity construction (Tripathy \& Mohapatra 2011: 93).

Maldonado-Torres' (2008) notion of coloniality of being extends the debate to the realm of the making of modern subjectivities and conceptions of humanism, where racial classification pushed Africans to the lowest rank of human ontology where even their being human was doubted. Modernist devices like development have been utilized to construct colonised people as those whose being was constituted by a series of 'deficits' (Escobar 2012: viii). It resonates with Fanon's definition of decolonisation as liberation that results in a new humanism - what Ngugi wa Thiong'o (1986) calls decolonising the mind. Fanon insists that the key failure of decolonisation in Africa is epistemological (1968: 209) - unless there is a reconceptualisation of thinking and doing, a radical negation of the colonial mindset, 
a new humanism cannot emerge. Fanon's vision for a new reality of socially constructed (racialised) subjectivities, who can narrate their own subjectivities is significant as an outcome and recommendation for the analysis provided in this paper. Crucial to decolonial epistemic perspectives is its locus of enunciation, signified by shifting the geographies of reason to the marginalised spaces. This does not mean that all contributions from marginal spaces are aligned with social justice or the public good because they are marginalised but we are highlighting Fanon's (1968) notion of prohibited spaces as the root of colonial rule. This control of space has become essential to neoliberal globalisation and the challenge is to transgress the colonial space and rethink the politics of space (Gibson 2011: xiii).

We acknowledge that the decolonial epistemic perspective does not attempt to claim universality nor neutrality. It is deliberately situated in an epistemic site like post-apartheid South Africa that experienced the negative consequences of modernity and is struggling to disrupt the colonial agenda. Maldonado-Torres (2008) introduced the reflection on agency of the dehumanised, an important category to relocate contemporary struggles and experiences of the 'Other' (e.g. the resurgence of mass resistance in civil society) in an effort to delink from the dominant narrative.

The basic formulation of decolonial delinking formulated by Quijano (2007), and central to our context, is that a robust analytic of the limits of Eurocentrism (as a hegemonic structure of knowledge and beliefs) is needed. Santos (2007) extended the term delinking to disobedience. Epistemic disobedience provides options to resist global designs to colonise the economy, authority, police and military enforcement, knowledges and being (Mignolo, 2011:45). It implies a rejection of the coloniality of power from western categories of thought. It is imperative to shift our thinking to a different space and 'beginning', to spatial sites of struggles rather than to a new temporality within the same colonial space. The latter is evident when traditionalists tinker with curriculum, include African texts as a gesture of tokenism, and engage in frivolous attempts at decolonisation. The challenge is to open the doors to another mode of thinking, by way of the experience and memory of the African struggles, indigenous knowledges, and other types of truths whose basis is not being but the coloniality of being (Mignolo, 2011:49). This different kind of thinking, enunciated from the colonial, barbaric, excluded and 'Othered' space, is a fundamental step in the disruption of the 'civilized' space that remains inert in institutional culture. The westernised university (Grosfoguel, 2013) as inherited in much of the world, has fostered an institutional culture where male white bodies are perceived as trustworthy generators of knowledge. The colonial subject responds to the civilising mission of the university by emulating and performing for the oppressor, a coloniality of doing that 
Bhabha labels as mimicry and the ambivalence of the colonial discourse. Mimicry is evident in English departments, where academics, oblivious to the dynamics of hegemony and in order to be recognised as custodians of 'high culture', aim to become more English than the English in their defence of the canon and exclusion of African writings (Chetty, 2010). Santos (2007) terms this exclusion of the Other, 'epistemicide'. Spivak refers to it as 'worlding' (1999), pointing out how colonised spaces have normalised western knowledge as sovereign.

\section{Methodology}

This exploratory study critically discusses the experiences, insights and reflections of facilitators working with different subjectivities (academics and students) in decolonial engagements across the university. Many workshops and seminars were organised to address the issue of decoloniality at the university and beyond. Across the many engagements (approximately 8-10), an average of 20 participants per workshop constitute our sample in this paper. At these workshops, a cross section of students, academics and administrators attended with a view to understanding what decoloniality and decolonisation mean. During these workshops, many significant insights and ideas were shared and discussed in relation to how participants had experienced or were experiencing the disruption that the decolonisation call had provoked in them and the university.

At each workshop, we sought consent from participants to use their anonymised data as the basis for our reflections. This would enable us to research and disseminate widely in the interest of knowledge sharing. Data include materials, field and concept notes, participants' reflections, and reflective narratives of the authors that were generated during workshops and seminars, in response to questions such as 'what is decolonisation' and 'how does decolonisation trigger or enable you and the academic project to expand and extend?

Using the concept of 'social cartography' as an analytical tool, we map the different responses to decolonisation and provide a critical analysis by unpacking the implications for decolonisation as a movement in higher education (HE) in a global South context. Social cartography is a participatory method of collective research that involves various modes of interpretation, narrative and reconfiguration. It embraces an integrative perspective where reality is understood as constructed socially and culturally by people, from their interpersonal and political experiences. People's experiences in turn have an influence on mental, graphic, subjective, discursive and material representations of the socio-cultural context. Social reproduction via such maps refers to how prevailing ways of seeing and 
doing things, understanding things and 'being' in the world often seem resilient against change (Tabensky and Matthews 2015: 26). Social maps are not positivistic; they provide 'a perspectivist orientation for which there are no facts, only interpretations, and no objective truths, only the constructs of various individuals and groups' (Best and Kellner,1992, p.22 cited in Paulston and Liebman, 1994).

The analytical framework we draw on (and adapt) is based on the work of Andreotti, et.al. (2015) who use social cartography as a frame to map tensions, paradoxes and contradictions in different responses to modernity. We refer to our frame as 'discursive spaces' in which different interpretations, conceptualisations, actions and emotions relating to decolonisation are created, formulated and housed. Social cartography is different to a geographic cartography in that it offers a comparative lens into the cultural values and differences between different and often competing knowledge claims and how they interrelate (Paulston, 2000). These social maps enable dialogue and discussion but also allow one to take a step back so as to consider a meta-view of what is happening on the ground. In this paper, we are using the social map as a heuristic to identify the different cultural values and beliefs in the discursive field of decolonisation in a particular setting.

The aim of this study is to see the opportunities available for academics, practitioners and facilitators working with decoloniality, to re-think traditional practices and discourses, and to re-imagine emergent and decolonial ways of thinking and doing. Our analysis shows that through tacit and explicit 'rules of the game', different responses 'regulate what is understood, what can and cannot be said, who can speak, and who must listen, whose educational perspectives are scientific and whose are unlearned and unimportant' (Kincheloe, Steinberg \& Gresson 1996: 30).

\section{Engaging with the data}

In this section, we trace the various textures of decolonisation across the university to map out how academics and students are taking up the call for decolonisation. The data reflects the range of responses elicited at the different sites, across the university and beyond. Participants at most of these workshops, seminars and meetings, found the events discomforting and disruptive, but for very different reasons. Decolonisation as a mechanism calls for a change and a break with western traditions, the colonial canon, dominant worldviews and limiting paradigms; all of which are dear to those wanting to maintain the status quo. Decolonisation also calls for a re-positioning and re-centering of that which is sacred, local, and Indigenous. This evoked different emotive responses that 
became illuminating for our study. The (re)turn to epistemological positions informed by Indigenous Knowledge Systems (IKS), although not a panacea for the total manifestations of this situation, does offer the possibility for creating a critical space for knowledge (re) production in the heart of dominant global knowledge circuits as well as serve as a challenge and corrective to the epistemic hegemony of the North (Walker, 2011:105)

It is important to reflect critically on who is engaging with the process and why (Mamdani, 2017) and what this means for decolonisation as a catalyst in the academy. How decolonisation is engaged with by different constituencies and agents holds important insights for ways that deepen the debates and create conditions for people to exercise their agency in the interests of social justice to offset traditional and dominant tropes. What follows is a reflection on and discussion of different responses by academics who attended and engaged in a multitude of events focused on decolonisation, from the start of the protests till the present. We discuss these strands across a spectrum as depicted in the table below:

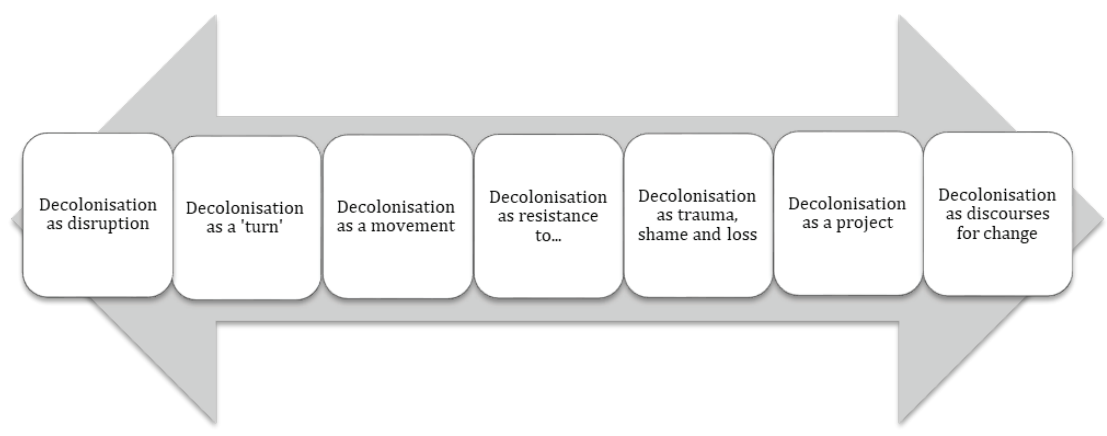

Figure 1: Spectrum of responses to decolonisation call

\section{Decolonisation as disruption}

When the academic project was disrupted in 2015 and 2016, decolonisation was initially seen as a fundamental 'attack' by mainly black student protesters on white academics (Mgqwashu, 2016), and by extension on the traditional nature of the university and of science. According to Bhabha (1994), decolonisation is more than an 'attack'; it is a necessary mode of articulation and production that 'interrupts, interrogates and enunciates', blurring the limitations of existing boundaries. Grosfoguel (2013) maintains that decolonisation disrupts our internalised and naturalised colonial frames of reference by displacing the 
cultural and knowledge practices that have been normalised through colonial sensibilities. Césaire (1972) in his assertion of 'negritude', rejected colonial thinking by asserting pride in African values while in South Africa, Biko's Black Consciousness was a form of a rejection of western imperialism in the 1970s.

Protesting students led this mode of articulation across campuses by highlighting sharp contrasts between inherited legacies of colonial practices through their performative acts of disruption and intentional subversion of the colonial university. At one university, protesting students organised a winter school to explore and present ways of working with knowledge, power, being and doing differently. This offered a decolonial option for students and academics to experience a different pedagogy - one of inclusion, learning, growing, facilitating and working together, to enact the principles of Ubuntu (Ramose, 2019).

The Decolonial Winter School has emerged as way to journey to a pedagogy that would subvert the authoritarian structure of knowing imposed by the current order of the Colonial University, and in this way, we actively take the next step towards actualising a decolonised education. As activists coming out of the \#MustFall Movements we are looking to create an alternative school that focuses not only on theory, but also DOING as a necessary praxis in Teaching and Learning (Decolonial Winter School, 2018).

The Curriculum Change Working Group, commissioned by the VC at one university to facilitate discussions across the campus on the topic of decolonisation during shutdown, also hosted many events that addressed provocative questions posed by activist students, but that engaged participants in thoughtful mediation and discussion, such as:

Who gets to create knowledge, for whom? What does knowledge do? Whose interests are served? Is the knowledge we produce relevant to the societies in which we live? (CCWG framework document, 2018)

Students also contested and disrupted academic and social traditions by drawing attention to the (ir)relevance of certain statues, colonial names of buildings, traditions at graduation ceremonies, representation in colonial artworks and so on (Shackville, 2018). 


\section{Decolonisation as a 'Turn'}

Some students and academics responded to decolonisation as the new 'turn', similar to the linguistic turn in early 1800 s or the cultural turn in the 1970s, where the 'turn' describes a shift in emphasis away from a positivist epistemology toward meaning in contemporary debates. The decolonial turn has at its theoretical centre, a focus on coloniality as the basis for inequality in the modern world, and seeks to respond and 'correct' this through a deep understanding of decoloniality as theory and praxis (Maldonado-Torres, 2011). The 'decolonial turn' embraces a pluralistic engagement with epistemologies and pedagogies that defy being constructed as 'uni-versal' knowledge, applicable to all, irrespective of context.

The 'turn' has also been co-opted and interpreted in expedient ways by some academics, who are quick to get on the publication bandwagon and write papers and chapters that focus on decolonisation. Although these invocations purport to be engaging with the theory, authors are 'thin on practice' and lead one to believe that decolonisation can be academicised as a cognitive activity only, without commitment to following through in the field of practice and its context. While these published works serve to increase the corpus of decolonisation literature to date, these attempts might not be regarded as an actual turn. At the heart of the decolonisation project is an aversion to appropriating the discourse of 'the context of exclusion and inequality' (Modiri, 2016) to suit neoliberal performativity. Neo-liberal managerialism, commodification of higher education and marketisation are characteristic of higher education globally (Olssen \& Peters, 2005) and it does not augur well to perpetuate this as the kind of scholarship the decolonial turn seeks to develop.

While new scholarship in this cognate field is necessary and welcome, we have observed that some academics engage only at this level. The danger here is that decolonisation becomes a textbook activity, relegated to 'armchair academics' who are able to churn out journal papers and books, commenting and theorising about the decolonisation moment, while others see themselves at the frontline, as it were, re-writing history and actually making things happen.

\section{Decolonisation as a movement of resistance}

At some sites where protests were led by students, resistance to the university's normative hegemony continued through ongoing decolonial disruptions. Traditional classroom practices and 'teacher' authority exposed the cultural assumptions and binary thought 
underlying the colonial narrative in faculties, departments, units and centres. Through resistance, decolonisation provided an alternative reading of the status quo by challenging traditional authority and power and hegemonic practices were critiqued for their essential and reductionist impact.

The most compelling iteration of decolonisation work has been in its performative value. At the heart of this work, we have observed how the decolonisation discourse moves academics to action that embraces African knowledge systems and thinkers in their research and teaching. In a move to free African minds from colonial influence and embrace a collective African identity that encompasses African ideas' (Modiri, 2016), academics and students who see decolonisation as a movement move seamlessly across artificial boundaries of race and class while acknowledging their contested identities as 'raced' and 'classed' subjects in a post-colonial dispensation.

Drawing on Mignolo's 'de-linking' as a performative discourse in decoloniality, we have observed how decolonisation acts as a space and a place of 'doing' where traditional values and beliefs, implicit in the curriculum content, are contested. We saw how new hybrid spaces mushroomed to shift the traditional space of academic labour. New subjectivities foregrounding 'who we are' and 'from where we speak' lead to the link between epistemological relevance and ontological depth that is critical to decoloniality. In this sense, decolonising knowledge is about shifting the geography of reason, which means opening reason beyond Eurocentric and provincial horizons, as well as producing knowledge beyond strict disciplinary impositions. As we saw, when academics and students engage with decolonisation as a movement, they seek to make explicit the links between the university and its social, political and economic links. Fanon moved the geography of reason towards the marginal, the marginalised, the refugees, the non-citizens, the undocumented and the illegal - finding new sources for truth and reality, namely for the emergence of new subjectivities that through their praxis create a new language (Fanon, 1968:47). This resistance of the colonial lens is the crux of Biko's (2004) principle of Black Consciousness, a delinking of the hegemonic imperialist reasoning as a strategy for new dimensions to emerge.

Decolonisation as a movement is thus both political and personal (Nakata, 2007). Decolonising knowledge is not simply about de-westernisation or rejecting western streams of knowledge. Nor is it about closing the door to European and other traditions. According to Ngũgĩ wa Thiong'o, it is about defining clearly what the centre is and mapping out the directions and perspectives that studies should take in an African university because Africa has to be placed at the centre. 
By doing this, we can transform our discursive range to embrace broader paradigmatic and disciplinary views. This requires an epistemic-ontological shift from colonial traditions universalised at a global level, to local epistemologies. In acknowledging the value and importance of indigenous and situated knowledge of the marginalised, the process of recognising and addressing the colonial wound is instantiated. This involves going beyond a critique of Eurocentricism to address and mourn the infinite loss when indigenous cultures were appropriated, and their contributions erased from world history (Modiri, 2016). The decolonial movement is about imagining and creating a new way of being and academics could start by interrogating their own cultural positioning and epistemological frameworks and expanding these to include other knowledge and pedagogical systems to restore those that have been eclipsed.

\section{Decolonisation as resistance to change}

Across the sites we engaged in, there was also resistance to decolonisation by academics and some students. In different spaces, black students reported that they were accosted to provide definitions and explanations:

Questions by many white academics, demand that we, black students explain to them what decolonisation means as if we should know all the answers simply because we are black and critiquing a white system. (Seminar Participants, 2016)

In departments and units that enjoy high status at the university through 'excellent' research outputs, good throughput rates and a ready supply of graduates to fill the market, there was resistance from academics who believed there is no need to change anything, because existing practices yield the desired results in specific degrees and produce the graduates 'we' want.

It is jarring to hear scholars in the sciences claim that unlike the humanities, their disciplines are ideologically neutral and hence not susceptible to decolonisation - despite the wealth of literature to the absolute contrary. (Modiri, 2016)

This position, according to wa Thiong'o, (1986) reproduces the same pedagogy that decolonisation seeks to break away from. Academics who resist decolonisation are reluctant to accept that students' experiences of being alienated and silenced in classrooms, 
count and matter (Behari Leak, Ramugondo, \& Kathard , 2016). The overarching critique from resisters was that decolonisation is 'hollow, extremist, lacking in nuance, unscholarly, essentialist and academically unsound' (Modiri, 2016). The reasoning is that if the curriculum is enabling access and success for the majority, others should find a way of coping by simply working harder (Rudin, 2017). This is an over-simplistic view. Black students experience exclusion as a result of systemic inequality on many different levels, including race, language, gender, class and ethnicity. Decolonisation is focused on opening up spaces for these students and many others, to be heard and seen and taken seriously.

\section{Decolonisation as trauma, shame and loss}

For many academics and some students, decolonisation debates trigger historical trauma, shame and a loss of the status quo and all that is comfortable, familiar and similar. In our workshops, many progressive and liberal white academics who considered themselves to be part of the anti-apartheid struggle in the 80 's registered an immense sense of guilt about being part of an oppressive regime and colonial heritage even though they were in principle, against notions of colonialism, patriarchy and racism. Traumatic for these white academics is their difficulty when:

...students make sweeping generalisations about race and coloniality which includes everyone white, everyone who is in a position of management, everyone with privilege. (Participants, 2017)

When confronted with generalisations, some academics noted that their reactions became defensive, which led to a withdrawal from further activity as a result of the guilt, pain and distress at acknowledging that they have been part of a history that 'is so unbearable!'

My privilege is built on this utterly terrible history, even if I didn't support what happened. (Workshop Participant, 2017).

Linked to guilt, many academics were filled with a sense of 'colonial shame', associated with vulnerability and lack of legitimacy. Colonial shame arises out of a historically passive relationship and lack of resistance to colonisation (Ramos 2017). To move away from colonial shame, people sometimes create a hero narrative. Frances Negron-Muntaner (2004) describes the relationship between shame and identity as 'largely made up of the 
desire to purge, want, deny, destroy, resignify (sic), and transfigure the constitutive shame [... from our bodies and public selves' (Ramos 2017: xiv). Some white academics were able to work with this affective domain, even if with difficulty:

For myself as a white person, the decolonisation conversation triggered the ability to sit with that emotion, and also recognise the common experience of the emotion, but from different lived realities.

Where white students and academics have been able to work with guilt and shame, it has been a healing process for them, and their discomfort inspired positive changes because it created a sense of transformative agency:

I left the session thinking a lot about the emotion of shame, what one does with it, how it can move one to the active process of decolonisation and how shame links to vulnerability [... ] and connects vulnerability and shame to empathy. Empathy being something healing, which for me is part of the decolonisation process.

The discourse of trauma has been used to elicit a sense of sympathy and understanding from others in the room, and where this has been the case, we have watched how decolonial spaces become misappropriated and manipulated by privileged and fragile sensibilities and sensitivities. Before long, black bodies in the room were in service of white trauma and white guilt and old tropes played themselves out again.

\section{Decolonisation as a 'project'}

In more conservative spaces in the academy, academics engage with 'decolonisation' or decoloniality as a project, with a positivist focus on timelines, objectives, deliverables, principal investigators and methods. Conceptualised as a project, decolonisation uses traditional research methods to produce outputs that deny the central intention of decoloniality. This approach is driven by an external locus of curiosity, motivated by a need to understand the concept 'decolonisation' sufficiently to be able to master it, as one would do with chess, for example.

Where academics are insistent on definitions and explanations, our involvement in these spaces is tantamount to a 'teach-in' where facilitators are expected to provide 'information' on decolonisation and do much of the labour by carrying the responsibility of 
'explaining' decolonisation. By focusing on the cognitive aspects, these academics manage the difficult affective aspects that are surfaced. This is translated as 'understanding' and is revealed when white academics begin 'splaining' to black academics what decolonisation is. They do this by deferring to dictionary definitions, as if the colonial authority of the 'dictionary' is itself uncontested and neutral, as the example below shows:

First, it's necessary to understand those two words: 'decolonisation' and 'education'. The Cambridge dictionary calls decolonisation 'the process in which a country that was previously a colony controlled by another country becomes politically independent'. 'Education', meanwhile, is what the Oxford dictionary calls 'the process of receiving or giving systematic instruction, especially at a school or university'. Placed together, then, the decolonisation of education means that a nation must become independent with regards to the acquisition of knowledge skills, values, beliefs and habits' (Workshop participant, 2016).

For people working in this frame, the main link is academic curiosity to explore some of the essential features so they can determine its application if they so choose. Even though this might be useful to some, it reduces decoloniality to a set of definitions and terminology. The real danger is that simplistic interpretations and appropriation can undermine the sophisticated project of decolonising and indigenising curricula. If this happens it might be difficult to reverse what might be seen as tokenistic attempts and trivial approaches to a very serious and deep systemic challenge.

\section{Decolonisation as a discourse for change}

Discourses are prevalent in any context and at any time they reflect the ideas, beliefs and values that exist in a cultural system and used by people at particular times. In a realist sense (Bhaskar, 1998), discourses have properties of their own to affect things and how people think. The discourse of decolonisation has enabled conversations to open up in ways previously not possible and is present now in classrooms as well as management meetings, enabling those previously excluded to find their voice again.

Overall, in the discursive domain, through contestation there has been an expansion of the register/discourse/lexicon of decolonisation; an increase in the appetite and the vocabulary to talk about it. The students shifted the public discourse and 'put the spotlight on redefining African knowledge, literature and academia'. This was a good starting point 
for many and has encouraged a new- found creativity to generate new ways of thinking and being. Minority cultural groups and those usually marginalised by society's hegemonic and heteronormative dispositions for example are in our discussions and consciousness, in ways not possible before.

Student activists in the decolonial movement have been vigilant regarding how the decolonial discourse is being engaged with. Students organised a Decolonial Winter School to put into practice the theoretical foundation of \#MustFall activism by engaging in an interdisciplinary and multi-dimensional space that tests the possible alternatives to Teaching and Learning, centralising the knowing of the student (as activist) in the university space. The aim of the decolonial school was to:

Invert the authoritarian structure of 'teacher as knower' and 'learner as vessel' [...]. the teaching praxis would be from perspective of the (black) student [... ] to feed pedagogical discourse from the pulse of the Decolonial Impulse which is invoked in all iterations of the MustFall movements. (Decolonial Winter School, 2018).

In a brief to all prospective presenters and facilitators at the winter school, the student organisers signalled a strong need to uphold tenets of decoloniality, that had become lost in iterations since the \#Fallist events in 2015:

At present, we feel the Decolonial Discourse has become elitist, existing in academic silos and private dinner tables; we want to invite others to the table in order to make an honest attempt at connecting the discourse with the practice. It is no longer enough to write papers and deliver lectures and consider ourselves to be doing decolonisation, we must connect with social activists in greater society who have been doing the social justice activism. (Decolonial Winter School, 2018).

\section{What does this all mean for decolonising the university?}

The discourses and approaches discussed above allow us to see a wide range of responses to decolonising the university. From these responses, we were able to identify an emergent social cartography that depicts four domains of thinking, being and doing in the academic arena. This cartography is discussed below in relation to Mamdani's claim (2017), that in any given site, there are the conservatives, the moderates and the radicals. Indeed, in our work across various sites in the sector, this has been the case. 
The conservatives at universities may be considered to be those individuals and groups of academics, management or students who are nostalgic about the way things were and believe fundamentally in a traditional maintenance of power so that the status quo, both academically and in terms of who accesses the university, is maintained.

The African university began as a colonial project, a top-down modernist project whose ambition was the conquest of society. The university was in the frontline of the colonial civilising mission. Properly understood, this civilising mission was the precursor to the structural adjustment programme and the World Bank and IMF loans that enforced conservative economic policy on indebted, newly independent economies (Mamdani, 2017).

One of the ways in which conservative ideas are reproduced at the university, Mamdani opines, is through responses to decolonisation such as this:

These are very dangerous ideas [... The risk of adopting student protesters' stance on 'decolonising education' is that South Africa rejects all the advances of modern medicine, education and science that originated elsewhere in the world. This would, for example, mean rejecting the use of penicillin, the yellow fever vaccination and HIV ARV drugs. None of these were developed in Africa (Wingfield, 2017).

Linking this domain with the data engaged with earlier, the conservatives are identified by their resistance to decolonisation or by their ridicule of decolonisation as an empty unnecessary project of angry black bodies. The conservatives experience the greatest loss or fear of loss and privilege; not just loss of familiar and comfortable ways of being and knowing but a more fundamental loss of power and prestige in the academic space. Driven by their need to conserve and preserve, conservatives, in being so loyal to their party positions, do not realise their own blind spots or prejudice; often their utterances reveal the deep-seated racism and classism they feel they are entitled to:

Yet what, precisely, is meant by decolonisation remains unclear. Those who shout the loudest and claim to know often end up making fools of themselves, for either their ignorance or the contradictions of their conclusions. The proposed rejection of science as a non-African, white Eurocentric imposition made news across the world for its utter stupidity or fundamentalism (Rudin 2017).

The moderates are 'in the middle' as it were, articulating from a walking-left-talking-right 
paradigm, still stuck within a colonial paradigm, but acknowledging that the university has to transform. The Eurocentric canon and western modes of thinking are still dominant and there is a patronising and condescending attitude towards African scholarship:

The old saying states that knowledge is power. If you own it, you can control those without it. Since so much knowledge about Africa doesn't sit on the continent, it's apparent that Africa lacks power in this regard (Chirikure, 2016).

It is the moderates who engage with scholarship mainly at the cognate level. i.e. decolonisation as a research inquiry. They aim to always articulate the right definitions, have a knack of getting into powerful organisations, committees and bodies in the university and draw from research, evidence for their claims to maintain the status quo. Mignolo (2011) and Spivak (1999) focus their question specifically to the moderates: 'who speaks for the human in human rights?' because of their tendency to serve as spokespersons for the marginalised Other by virtue of their academic engagement as political activists. They were also the most vociferous group during the student revolt and commented in the media that social protests belong to the world outside; the university is a space for knowledge production. Hence, there is a performative contradiction among the moderates to deny the very humanity of the oppressed. They also noted their deep trauma at being labelled 'colonial' and 'racist' by black students in spite of their long-standing contribution to student welfare and their 'hard-earned' credibility by trying to transform institutional culture. The moderates are in an ambivalent space: on the one hand they support transformation; on the other they also support continuity. During the \#RMF disruptions, it was the moderates who, believing that the statue should stay, posed the rhetorical questions to students: 'But what about our history?' 'Should we be erasing history?'

On the question of erasure, the radicals differ fundamentally with the conservatives and the moderates, asserting that it is only through disruption of the colonial agenda that decolonisation can succeed in its goals. They foreground the duty of both academics and students in the post-apartheid higher education system to contribute to social justice and development; research should have a social impact and not be stuck in the realm of elitist research games. They question the university as a powerful mechanism of social exclusion and injustice, through colonial thinking, structures, cultures and practices. The radical academics acknowledge their (sometimes complicit) role in social exclusion with regard to epistemological and ontological issues associated with learning and teaching, curriculum development and pedagogical practice. They not only supported the students in the call 
to decolonise the intellectual spaces in Higher Education but took up the baton to create spaces for contesting the dominant epistemologies, ontologies and methodologies in classrooms, seminar spaces and public gatherings. Their engagement with the scholarship of decolonisation centred on ways to interrupt the dominant discourse; to halt the ways in which new and different scholarly thought and writing was suffocated by the colonial agenda.

For the radicals, the contradictions and hypocrisies in the academy are starkest as they sometimes have to position themselves away from the centre to influence the centre. To be radical is to understand one's position relative to the centre. But from this positioning and given the contractual obligations that they have to fulfil as employees and workers, the academy places them in the precarious position of being hyper-visibilised. This means the spotlight is always on them, from line managers, Deans and colleagues. This comes with its consequences, one of which is a critical self-reflexivity that is sometimes difficult to embrace, as radicals are constantly reacting and responding to critique from others. In some cases, radicals are compromised when they have to acknowledge that their own bifurcated ways of knowing, acting and being have reinforced and reproduced oppressive institutional cultures, making their own positionality with regard to the neo-colonial programme complex and complicated. For radicals, bringing, marginalized knowledges into the university for example, is a huge risk as a great deal of scepticism is applied to Indigenous knowledge (Ahenakew, 2016). When marginalised knowledges are engaged with by academic knowers who are far removed from the known (Mbembe, 2016), these knowledges struggle to compete with western, global north epistemes that have gained such traction and dominance in the colonial academy.

Adding to Mamdani's three domains, our research has illuminated a fourth domain. Again, using social cartography as a heuristic and analytical tool, we have observed that a fourth discursive domain, in which responses to decolonisation are articulated and enunciated from left and right of the decolonisation spectrum, has emerged. We refer to this domain as the hybrids. 


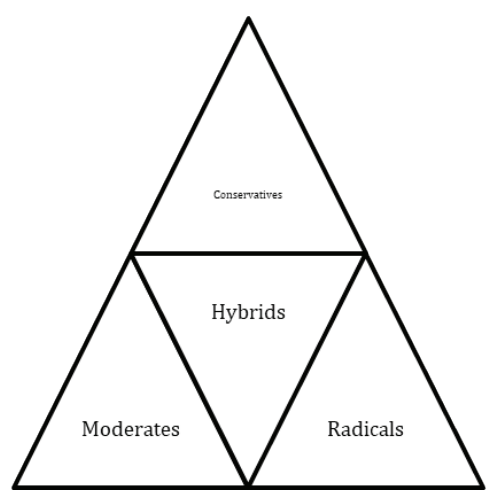

Figure 2: Social mapping of discursive domains

In this group, academics straddle two domains, namely conservative-moderate and moderate-radical. They are a force to reckon with as they can easily swing from the left to the right of the socio-political spectrum. Depending on the stakes, the hybrids are able to appropriate the decolonisation discourse and use it to their advantage, either in written or oratory form, even though they themselves might not believe a word they say. The hybrids wear the masks of being neither here nor there but being everywhere and nowhere at the same time. One might recognise a hybrid as vocal and vociferous at a public university gathering and then be perplexed by his or her silence on the same subject or topic, in a management meeting or an at academic event. The hybrids are made up of a range of positionalities that are at times in conflict with each other and with the movement, vacillating between complicity and resistance. We would caution that hybridity in our social cartography across the university yields a negative outcome and profile, and in our experience, we see this group as mainly complicit with coloniality but able to strategically manoeuvre as the context dictates.

We must re-iterate that the identification of the hybrids is based on the limited data we have worked with in this study. There might well be many other and different positionalities within this domain that are complex and need to be grappled with. For example, adopting a hybrid position might be extremely useful when dealing strategically with a variety of stakeholders and interlocutors from the conservatives and moderates or to advance a particular aspect that takes into account all voices. We are aware that being able to move across positions is dangerous and might yield options that do not coincide with the purpose and goals of the decolonial project, as we understand it. In this paper, we wanted to illustrate 
the domains that emerged and to foreground intentionality, legitimacy and authenticity as key drivers to align with purpose and goals and to get a sense if those involved across the spectrum of decolonisation are in it for the reasons the movement aligns to; and if they will be there when the chips fall and their backs are against the wall again.

\section{Conclusion}

The analysis of responses by participants in the seminars and workshops on decolonisation provided insights on how different academics are making sense of the decolonial movement, based on their own social and political agendas. Integral to these responses are the geographical spaces from which academics speak, their ideological orientations, subject-positions (racial, gender and class identifications), and the historical processes that inform their knowledge-claims.

Using a cartographic analysis of the responses, we confirm that in the university space, three domains do exist: conservatives, moderates and radicals (Mamdani, 2017). Resistance to change signals a significant fear of loss of power and privilege of supporters of the hegemonic project as well as an investment in preserving colonial academic traditions. Such insights also enable a greater awareness of attempts to neutralise decolonisation into a formulaic, recipe-driven easily managed and delivered 'project', so that these can be thwarted.

There is a danger, however, in conceptualising decolonisation only as an academic project as this may contradict the key intention of disruption of power and lead to superficial interludes (waiting for the dust to settle), limited to the level of epistemological window-dressing. We therefore need to be circumspect of engaging only in decolonial intellectual endeavours as they are fraught with tensions and contradictions within academia (Shahjahan et al, 2017).

There needs to be an assertion of an ontological depth that reflects a relational way of living and being that is African. We need to recognise and actively work against the alienation and marginalisation of black bodies and women in particular to stymie the perpetuation and reproduction of coloniality, especially if such perpetuation is counterproductive to the project of social justice. Universities, specifically the historically white institutions, need to engage with greater urgency and more critically with its be-ing through the transformation of institutional culture, i.e. the lived experience of the university by all those who inhabit it, including students, academic staff, management, support staff, workers and members of the public who come into contact with the institution. 
Decolonised thinking stems from the idea that the diversity of the world is inexhaustible and that such diversity still lacks an adequate epistemology. Decolonial being invites us to be 'self-reflexive' of universalising 'alternatives' (Ahenakew, 2016) and to mobilise a relationship to and with knowledge from a strong ontological disposition. To decolonise the university is to change it with the aim of creating a critical cosmopolitan pluri-versalism - a task that involves the radical reclaiming of alternate ways of thinking and being, by interrupting the colonial narrative. It embraces, via a horizontal strategy of openness, a dialogue among different epistemic traditions and different ontological positions.

\section{References}

Ahenakew, Cash. 2016.“Grafting Indigenous Ways of Knowing onto Non-indigenous Ways of Being: The (Under-estimated) Challenges of a Decolonial Imagination.” International Review of Qualitative Research, 9 (3): 323-40.

Andreotti, V., Stein, S., Ahenakew, C. \& Hunt, D. 2015. Mapping interpretations of decolonization in the context of higher education. Decolonization: Indigeneity, Education \& Society, 4(1):21-40

Behari-Leak, K., Ramugondo, E. \& Kathard, H. 2016. Students in South Africa feel unheard.

Here's one way to listen, The Conversation, 11 October. https://theconversation.com/ students-in-south-africa-feel-unheard-heres-one-way-to-listen-66805

Bhabha, H. K. 1994. The location of culture. London: Routledge.

Bhaskar, R. 1998. Philosophy and scientific realism. In M. Archer, R. Bhaskar, A. Collier, T. Lawson, \& A. Norrie (Eds.), Critical realism: Essential readings (pp. 16-47). London: Routledge.

Biko, S. 2004. I write what I like. Johannesburg: Picador.

Chetty, R. 2010. The vintage book of South African Indian writing. Johannesburg: STE Publishers.

Césaire, A. 1972. Discourse on colonialism. New York: Monthly Review Press.

Charlie, A. \& Dougan, L. 2018. Shackville two years on - a perspective from the student who graduated. Daily Maverick, February 2018. https://www.dailymaverick.co.za/ article/2018-02-28-no-filter-volume-4-shackville-two-years-on-a-perspective-fromthe-student-who-graduated/

Chirikure, S. 2016. Transforming higher education: first comes knowledge, then curriculum, The Conversation, 8 September. https://theconversation.com/transforming-highereducation-first-comes-knowledge-then-curriculum-64833 
Dastile, N. P., \& Ndlovu-Gatsheni, S. 2013. Power, knowledge and being: Decolonial combative discourse as a survival kit. Alternation, 20(1), 105-134.

Decolonial Winter School. 2018. https://www.news.uct.ac.za/article/-2018-06-22-stepstoward-decolonised-learning

Duma, S. 2017. The rise of disruption politics and radical social entrepreneurship. News 24 . Retrieved from

https://www.news24.com/Columnists/GuestColumn/the-rise-of-disruptionpoliticsand-radical-social-entrepreneurship-20170713

Escobar, A 2012. Beyond the Third World: Imperial Globality, Global Coloniality and Anti-Globalization Social Movements. Third World Quarterly 25,1.

Fanon, F. 1968. The wretched of the earth (trans. C. Farrington). New York: Grove Press.

Farber, T. 2015. "UCT in Turmoil." Times Live, March 17. https://www.timeslive.co.za/ news/southafrica/2015-03-17-uct-in-turmoil/

Gordon, L. (2019). Black aesthetics, black value, and challenges of liberation and political life. Presentation at the Unisa Decoloniality Summer School, Pretoria, SA.

Gibson, N.C. 2011. Fanonian practices in South Africa. Scottsville: University of KwaZulu Natal Press.

Grosfoguel, R. 2013. The structure of knowledge in Westernized Universities: Epistemic racism/sexism and the four genocides/epistemicides of the long 16th Century. Human Architecture: Journal of the Sociology of Self-Knowledge, 11(1), 73-90.

Kincheloe, J., Steinberg, S. \& Gresson, A.D. 1996. Measured lies. New York: Martin's Press.

Liebman, M. \& Paulston, G.R. 1994. Social cartography: A new methodology for comparative studies. Compare, Taylor \& Francis.

Maldonado-Torres, N. 2008. Religion, conquete et race dans la foundation $\mathrm{du}$ monde modern/colonial. In Mohamed Mestiri, Ramon Grosfoguel and El. Yamone Soum (Eds.), Islamophobie dans le monde modern, 205-238. Paris IIIT.

Maldonado-Torres, N., 2011. Thinking through the decolonial turn: Post-continental interventions in theory, philosophy, and critique-An introduction. Transmodernity: Journal of Peripheral Cultural Production of the Luso-Hispanic World, 1(2).

Mamdani, M. 1996. Citizen and subject: Contemporary Africa and the legacy of late colonialism. Princeton: Princeton University Press.

Mamdani, M. 2017. TB Davie Memorial Lecture: https://www.news.uct.ac.za/ article/2018-05-30-mamdani-rejoins-uct 
Mgqwashu, E. 2016. Universities can't decolonise the curriculum without defining it first.

The Conversation. https://theconversation.com/universities-cant-decolonise-thecurriculum-without-defining-it-first-63948

Mignolo, W. 2011. Epistemic Disobedience and the Decolonial Option: A Manifesto. Journal of Peripheral Cultural Production of the Luso-Hispanic World, 1(2):44-67.

Modiri, J. 2016. In the Fall: Decolonisation and the rejuvenation of the academic project in South Africa. Opinionista. https://oppidanpress.atavist.com/ decolonisation

Nakata, M. 2007. The cultural interface. The Australian journal of Indigenous education. 36 Supplement. pp $7-14$.

Nakata, N. M., V. Nakata, S. Keech, \& R. Bolt. 2012. Decolonial goals and pedagogies for Indigenous studies. Decolonization: Indigeneity, Education \& Society, 1(1), 120-140. Retrieved from

https://jps.library.utoronto.ca/index.php/des/article/view/18628/15551

Negron-Muntaner, F. 2004. Boricua Pop: Puerto Ricans and the Latinization of New York. New York: New York University Press.

Olssen, M. and Peters, M.A. 2005. Neoliberalism, higher education and the knowledge economy: from the free market to knowledge capitalism, Journal of Education Policy, 20(3): 313-345

Paulston, R. G. 2009. Mapping comparative education after postmodernity. In R. Cowen and A.M. Kazamias (eds), International Handbook of Comparative Education (pp. 965990). Springer Science.

Quijano, A. 2007. Coloniality and Modernity/Rationality. Cultural Studies, 21(2-3):16878.

Ramos, A.T. 2017. Colonial shame and its effect on Puerto Rican culture. PhD dissertation. University of Texas, Arlington. USA

Ramose, M. 2019. A philosophical investigation into the conceptual history of decolonisation in Africa. Presentation at the Unisa Decoloniality Summer School, Pretoria, South Africa.

Rudin, J. 2017. Deconstructing Decolonisation: Can racial assertiveness cure imagined inferiority? https://www.dailymaverick.co.za/opinionista/2017-01-22deconstructing-decolonisation-can-racial-assertiveness-cure-imagined-inferiority. (Accessed 10 July 2018)

Santos, B. de S. 2007. 'Beyond Abyssal Thinking: From Global Lines to Ecologies of Knowledge.' Review, XXX(1), 45-89. 
Shahjahan, R. A., Blanco Ramirez, G., \& Andreotti, V. D. O. 2017. Attempting to imagine the unimaginable: A decolonial reading of global university rankings. Comparative Education Review, 61(1).

Spivak, G.C. 1999. A critique of postcolonial reason. Boston: Harvard University Press.

Tuck, E. \& Yang, K.W. 2012. Decolonization is not a metaphor. Decolonization: Indigeneity, Education \& Society, 1(1), 1-40.

UCT Curriculum Change Framework UCT. 2018. http://www.uct.ac.za/sites/ default/ files/image tool/images/328/teaching/ccwg/UCT-Curriculum-Change-Framework. pdf

Walker, C. 2011. How Does It Feel to be a Problem?: (Local) Knowledge, Human Interests, and The Ethics of Opacity. Transmodernity: Journal of Peripheral Cultural Production of the Luso-Hispanic World, 1(2): 104-121.

wa Thiong'o, N. 1986. Decolonizing the mind: The politics of language in African literature. Nairobi, Kenya: Heinemann Education Publishing Ltd. 